Winter 2014

\title{
Sinister Translations: Law's Authority in a Post-9/11 World
}

Jothie Rajah

American Bar Foundation, jrajah@abfn.org

Follow this and additional works at: https://www.repository.law.indiana.edu/ijgls

Part of the International Law Commons

\section{Recommended Citation}

Rajah, Jothie (2014) "Sinister Translations: Law's Authority in a Post-9/11 World," Indiana Journal of Global Legal Studies: Vol. 21 : Iss. 1 , Article 5.

Available at: https://www.repository.law.indiana.edu/ijgls/vol21/iss1/5

This Symposium is brought to you for free and open access by the Law School Journals at Digital Repository @ Maurer Law. It has been accepted for inclusion in Indiana Journal of Global Legal Studies by an authorized editor of Digital Repository @ Maurer Law. For more information, please contact rvaughan@indiana.edu.

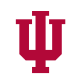

JEROME HALL LAW LIBRARY

$$
\text { INDIANA UNIVERSITY }
$$

Maurer School of Law
Blooming ton 


\title{
Sinister Translations: Law's Authority in a Post-9/11 World
}

\author{
JOTHIE RAJAH*
}

\begin{abstract}
What does the killing and burial of bin Laden tell us about the sites, sources, and nature of law's authority in a post-'9/11' world?' If law is constituted by "acts of language [that] are actions in the world," then the law embodied by these events is discernible through an analysis of Obama's announcement on the killing of bin Laden. Obama's announcement avoids the term 'law' yet makes present the relationship between 'law,' 'justice,' legitimacy, and violence. Through critical theory on language, translation, and political myth, this paper explores the translations at work in constructing law's authority for a post-9/11 world.
\end{abstract}

\section{INTRODUCTION}

\section{A. Embodying Law's Authority}

Osama bin Laden was killed by U.S. Special Forces in his home in Pakistan on May 1, 2011 and later buried at sea. His killing, as signified

* Jothie Rajah is Research Professor at the American Bar Foundation, Chicago. She holds a Ph.D in Law from Melbourne Law School and is the author of Authoritarian Rule of Law: Legislation, Discourse and Legitimacy in Singapore (2012). For generous advice, probing questions, and encouragement that helped transform ideological and intellectual distress into a research project, the author is especially grateful to Bonnie Honig. For soldiering through a barely readable early draft, the author is deeply indebted to Susan Shapiro. For thoughtful comments on various versions, the author warmly thanks Rick Abel, Fred Aman, Andrea Ballestero, Carolyn Bernstein, Colin Ford, Terry Halliday, Iza Hussin, Eve Lester, Joe Margulies, Amy Myrick, Matthew Nicholson, Pooja Parmar, Angela Spinazze, Umut Turem, and Peer Zumbansen. Amy Myrick has been an invaluable research assistant.

1. In (at least) the instance of first use, I place the term 'law' and other terms key to the analysis of this argument (such as 'rule of law,' 'justice,' and '9/11') in single quotation marks to visually signify that I problematize these terms as constructs and categories.

2. JaMes BOYD White, JUSTICE AS TRANSLATION, at ix (1990).

Indiana Journal of Global Legal Studies Vol. 21 \#1 (Winter 2014)

(C) Indiana University Maurer School of Law 
by the secretive burial at sea and the 1:00 a.m. raid on his home, is shrouded. Enacted in darkness, with the material reality of his body annihilated when slipped into unmarkable spaces, ${ }^{3}$ it is as if the killing of this man is beyond the reach of 'law': beyond capture, trial, sentencing, and most potently, beyond a burial that acknowledged his (human) ties to kin and community. This was a killing that enacted the power to not just take life, but to take death. ${ }^{4}$ The burial at sea is surely emblematic of an approach to counterinsurgency "predicated on eradicating the identity and existence of the Other, not just controlling the illicit use of violence." 5

What does the killing and burial of bin Laden tell us about the sites, sources, and nature of law's authority in a post-'9/11' world? ${ }^{6}$ If law is regarded as more than positive rules, if law is "the creation of a world of meaning"7 constituted by "acts of language [that] are actions in the world," 8 then the killing and burial of bin Laden are rule making and norm shaping. As Margaret Davies explains,

we think that there is some place that [knowledge] comes from which is external to ourselves. . . . [A]gainst this I would like to suggest ... that there are no rules out there . . . but that they exist only in reality, that is, only because we live them, we continually create and transform rules as we exist. There is no absolute place where they are all fixed, and to which we can refer to find their authentic form. Law is embodied, as we are,

3. The very materiality of dead bodies facilitates their political lives. See KATHERINE Verdery, The Political Lives of Dead Bodies: Reburial and Postsocialist Change 27 (1999) (a study of dead body politics in post-Communist Eastern Europe).

4. As Verdery notes, immense political symbolism attaches to death rituals and beliefs, notions of the "proper burial," and national and international contexts relating to particular dead bodies. VERDERY, supra note 3, at 3 . The dead bodies of the "named and famous" have a heightened significance, and shaping the social visibility of a dead body is part of the larger process of political transformation. See id. at 13-20.

5. Alison Brysk, Human Rights and National Insecurity, in NATIONAL INSECURITY AND HuMAN RightS: DEMOCRACIES DEBATE COUNTERTERRoRISM 1, 5 (Alison Brysk \& Gershon Shafir eds., 2007) (emphasis added).

6. See Generally RICHARD JACKSON, Writing THE WAR ON TERRORISM (2005) (arguing that the rhetoric used after $9 / 11$ has justified the war on terrorism). I use this shorthand with some regret that it has become so convenient to use. Jackson warns of the bundle of meanings and risks attached to the way in which the use of ' $9 / 11$ ' works to "erase the history and context of the events and turn their representation into a culturalpolitical icon where the meaning of the date becomes both assumed and open to manipulation[,] . . . [a] mythologising practice." Id. at 7.

7. WHITE, supra note 2 , at ix.

8. White is elaborating upon Wittgenstein's "famous sentence" that "[t]o imagine a language means to imagine a form of life." Id. 
and denying this is only a way of making life and law easier by pretending that rules are an absolute justification. ${ }^{9}$

In short, this killing and burial are law. At the risk of belaboring the point, if 'law' is embodied by the material and discursive reality of rules we live, create, and transform, and we cannot imagine ourselves in relation to 'law' outside of language, ${ }^{10}$ then the sites of 'law' are not limited to courtrooms and legislatures. 'Law' is (also) enacted in the mediatized public sphere. Thus, rather than looking to doctrinal law, I explore the question of law's post-9/11 authority through an analysis of a text legitimizing the killing: Obama's announcement on the killing of bin Laden, Remarks by the President on Osama bin Laden (hereinafter the "Remarks," provided as Appendix A).11

As 'law,' the Remarks make present the relationship between 'law,' 'justice,' legitimacy, and violence; a relationship this paper explores through critical theory on language and power and theory relating to processes and dynamics of translation. However, before going further, I should perhaps make explicit that this analysis is informed by a normative position on the relationship between 'law' and 'justice' in which 'law' is understood as the vehicle of an aspiration towards 'justice.' In her influential Just Silences, Mariane Constable traces a range of ways in which law and justice relate inextricably to each other, such that the contemporary dominance of legal positivism cannot, through its silences on 'justice,' be understood as effecting erasures of 'justice.'12 Ironically, the text this paper centers on, the Remarks, articulates the term that contemporary 'law' typically silences'justice'-even as it is silent as to (an explicit) 'law.' Prising open the meanings the Remarks construct for 'justice,' and for an absent but still

9. Margaret Davies, Asking THE LAW Question 4 (1994).

10. There is a large body of literature arguing and demonstrating the impossibility of thinking 'law' outside of 'language.' Some important references include MICHEL Foucault, THE ARCHEOLOGY OF KNOWLEDGE AND THE DISCOURSE ON LANGUAGE 215-237 (1972); WhITE, supra note 2; MARIANNE CONSTABLE, JUST SILENCES: THE LIMITS AND Possibilities of MODERn LAW 14 (2005); RobERT M. COVER, NARRATIVE, VIOLENCE AND THE LAW: THE EsSAYS OF RoBERT COVER (Martha Minow, Michael Ryan \& Austin Sarat eds., 1995).

11. President Barack Obama, Remarks by the President on Osama bin Laden, Address in the East Room (May 2, 2011), available at http://www.whitehouse.gov/the-pressoffice/2011/05/02/remarks-president-osama-bin-laden [hereinafter Remarks by the President]. A copy of the Remarks is appended at Appendix A, and any reference to the Remarks without citation refers to Appendix A.

12. ConstABle, supra note 10. 
speaking 'law' and 'rule of law,' is the endeavor at the heart of this paper.

In mapping the ways in which the Remarks do and do not use 'law,' 'justice,' and 'rule of law,' I have found the analytic lens of translation invaluable because, as the discussion below elaborates, translation brings within its conceptual grasp the primacy of affect in meaningmaking, and the manner in which modality and affect might relate to normative and systemic continuities, discontinuities, and distortions. Additionally, the thematic concern of this collection of papers with regulatory translations highlights that although 'law,' 'justice,' and 'rule of law' have regulatory force in national and transnational arenas, ${ }^{13}$ and regulation is a site in which the processes of translation are richly in evidence, ${ }^{14}$ the workings of translation in the regulatory field of 'rule of law' discourse are just beginning to be explored.15 This paper's deployment of the concept of translation helps illuminate some of the law-making dynamics at work in the Remarks that may otherwise escape analytic attention.

13. For some examples of the literature, see generally KAMARI MAXINE CLARKE, FICTIONS OF JUSTICE (2009) (exploring the fraught question of legitimacy in sub-Saharan Africa with regard to international criminal justice); LAW AND DISORDER IN THE Postcolony (Jean Comaroff \& John L. Comaroff eds., 2006) (demonstrating that postcolonies are interpellated by governance structures that, inter alia, criminalize poverty and perpetuate corruption even as they fetishize law); TAMIR MOUSTAFA, THE STRUgGle For Constitutional POWER (2007) (examining the politics, processes, and ideology of the Egyptian Supreme Constitutional Court); JOTHIE RAJAH, AUTHORITARIAN RULE OF LAW: LEGISLATION, Discourse AND LEGITMMACY IN SiNGAPORE (2012) (demonstrating how the institutions, politics, and histories of 'rule of law' can be disaggregated to simultaneously foster economic success but also civil and politic repression); THE POWER OF LAW IN A TRANSNATIONAL WORLD (Franz von BendaBeckmann, Keebet von Benda-Beckmann \& Anne Griffiths eds., 2009) (examining how, under conditions of legal pluralism and in a transnational world, social processes and power effect the constitution and reconstitution of law); RONEN SHAMIR, THE COLONIES OF LAW (2000) (analyzing the secular, nationalist, and anti-colonial ideology of the Hebrew Law of Peace in British-ruled Palestine).

14. Andrea Ballestero \& Umut Türem, Opening Remarks at the conference "Regulatory Translations: Expertise and Affect in Global Legal Fields" (May 16-18, 2013), organized by Bogazici University, Indiana Journal of Global Legal Studies, and Rice University.

15. For examples see generally SALly ENGLE MERRY, Human RightS and GENDER VIOLENCE: TRANSLATING INTERNATIONAL LAW INTO LOCAL JUSTICE (2006) (exploring the tensions between elite global formulations of human rights law and grassroots responses); ANNELISE RILES, Collateral KNOWLEDGE: LEGal REASONING IN THE Global FinanCial MARKETS (2011) (tracing the role of actors on the ground as de facto financial regulators); AnnJanette Rosga, The Traffic in Children: The Funding of Translation and the Translation of Funding, 28 PoLAR: POL. \& LEGAL ANTHROPOLOGY REV. 258 (2005) (exploring translation as an analytic concept and as a dynamic informing global knowledge sharing on the trafficking of children). 
Briefly, I argue that the Remarks and its accompanying narrative legitimize the killing by constructing an account of law's authority through a bifurcated translation of notions of state legitimacy. Relying first on James Boyd White's argument that translation is a process that must engage with the affective primacy of gestural, social, and relational meaning, ${ }^{16}$ and second, on Walter Benjamin's notion of translation as mode, ${ }^{17}$ I argue that the Remarks deploy gestural, social, and relational modalities of legitimacy that predate $9 / 11$ to assert continuing legitimacy for a mode of state power that, post-9/11, represents a normative and institutional rupture. This rupture resides in a fresh uncoupling of 'law' and 'justice'; an uncoupling that inverts legal positivism's loquacious 'law' and silent 'justice'18 to instead silence 'law' while celebrating a 'justice' embedded in political myths of 'nation.'

The second limb of this bifurcated translation relates to the extensive invocation of affect, and, in particular, the affect of significance generated by political myth, ${ }^{19}$ as the legitimizing foundation for an account of 'justice' that needs no reference to the processes, institutions, and actors of 'law.' It is in this regard that the translation becomes sinister: modes of signifying legitimacy drawn from pre-9/11 (gestural, social, and relational) texts are retained even as norms, values, and systems are rescripted for a post-9/11 world.

This bifurcated translation is rendered seamless and whole by the womb-like familiarity of political myth's affect, ${ }^{20}$ such that generally unexamined beliefs about the exceptionalism and ascendancy of the United States as 'nation' become an alternative to 'law'-in its conventionally understood institutional and procedural presences-as a foundation for state authority. If, before $9 / 11$, state legitimacy resided in a law understood as restraints on state power, ${ }^{21}$ and more explicitly in

16. WHITE, supra note 2 , at 233.

17. See Walter BenJamin, The TASK OF THE TRANSLATOR (Harry Zohn trans., 1968) (1923), reprinted in THE TRANSLATION STUDIES READER 15, 16 (Lawrence Venuti ed., Taylor \& Francis e-Library ed. 2004) (2000).

18. See generally CONSTABLE, supra note 10.

19. See ChlaRa BotTiCi, A PHILOSOPHY OF POLITICAL MYTH 116-133 (2007) (theorizing the forces that move people to act on the basis of arational elements).

20. Key components of political myth that allow it to "bypass critical scrutiny" are invisibility, ubiquity, and a powerful grip on our psyches. Joanne Esch, Legitimizing the "War on Terror": Political Myth in Official-Level Rhetoric, 31 PoL. PSYCHOL. 357, 360 (2010).

21. For some useful succinct reviews and analysis in the extensive literature on law, politics, and legitimacy, see David Clark, The Many Meanings of the Rule of Law, in LAW, CAPITAlism AND POWER IN ASIA: The RUle of LAW AND LEGAL InSTTTUTIONS 28, 29-31 (Kanishka Jayasuriya ed., 1999); MARTIN LOUghlin, SwORD AND ScALES: AN EXAMINATION OF THE RELATIONSHIP BETWEen LAW AND POLITICS (2000); BRIAN Z. TAMANAHA, ON THE Rule OF LAW: History, Politics, THEORY 114-126 (2004). 
visible legal institutions, processes, and actors (such as judicial proceedings conducted in the public domain), 22 then post-9/11, the translation effected by the Remarks locates 'justice' in spaces and practices apart from 'law.' In short, in an abandonment vividly enacted through the absence of the term 'law,' the Remarks discard 'law' as a basis for state legitimacy.

In contrast to a discarded law, 'justice' is enlivened by the Remarks' narrative of bin Laden's culpability in perpetrating an extreme violence that has caused the American people extreme grief and trauma. The Remarks present counterterrorism, intelligence, and military personnel as a new cast of determined and heroic justice actors, able to shift the nation away from grief and trauma and toward the victory of killing bin Laden. In so doing, these new justice actors enact the greatness of the United States as nation and repair the trauma of 9/11. The killing becomes emblematic of justice as a redemptive and retributive felt substitute for law. ${ }^{23}$ In this way, the Remarks effect a troubling translation of state authority away from 'law' toward a 'justice' that relies on affect, entrenched political myths of U.S. identity, and a mode of translation that bifurcates texts of legitimacy to reconfigure the grounds of law's authority in a post-9/11 world.

\section{B. From No Law to Lots of Law}

Two years after the killing of bin Laden, President Obama delivered a major policy speech calling for the United States to conduct itself in a manner that upholds the rule of law when addressing terrorism (Remarks by the President at the National Defense University, hereafter the Drone Policy Speech). ${ }^{24}$ While it is beyond the scope of this paper to fully engage with the Drone Policy Speech, it is important to highlight that in the Drone Policy Speech, the word 'justice' is sparingly used, but 'law' and 'rule of law' feature prominently, and repeated reference is made to the need for, and importance of, institutions, actors, and

22. But see Joseph Margulies, What Changed When Everything Changed: 9/11 AND THE MAKING OF NATIONAL IDENTITY 91-111 (2013), in which Margulies argues that, from 1963 to 2013 , "the idea of the rule of law has changed from a restraint on the state (in order to protect individual liberty) into a weapon of the state (in order to enable the state to identify, seize, imprison, and punish those who threaten a blameless 'us')," id. at 91 (emphasis in original).

23. See Thane Rosenbaum, Payback: The CASE For Revenge 1-2 (2013), for the troubling argument that 'justice' is equivalent to "revenge." The killing of bin Laden is one of the instances of an indistinguishable justice/revenge considered by Rosenbaum. Id. at 8 .

24. President Barack Obama, Remarks by the President at the National Defense University (May 23, 2013), available at http://www.whitehouse.gov/the-press-office/2013/ 05/23/remarks-president-national-defense-university [hereinafter Drone Policy Speech]. 
processes associated with 'rule of law.' When juxtaposed, the absent 'law' of the Remarks and the hyper-present 'law' of the Drone Policy Speech surely add up to a recognition that the killing and burial of bin Laden have significantly undermined law's authority in a post-9/11 world. ${ }^{25}$

The Drone Policy Speech has called for a range of measures that may or may not repair some of law's damaged authority. ${ }^{26}$ However, the Drone Policy Speech cannot undo the law embodied by the Remarks and the killing and burial of bin Laden. By being alert to the manner in which translation has been at work in rendering the 'law' of this killing, the Remarks will help us to see these processes at work in continuing reformulations of 'law,' 'justice,' and 'rule of law,' and, hopefully, better equip us to penetrate accounts of law, justice, and rule of law so as to facilitate critical engagement and social action.

\title{
I. TRAnslating Law: MisRUle, Mode, AND AFFECT
}

\section{A. Translation as Misrule}

In its common-sense understanding, ${ }^{27}$ translation happens when an expert, fluent in at least two languages, works with a text originally authored in one language to render that text into another. ${ }^{28}$ In other

25. However, by marking the killing of bin Laden as a necessary and lawful exception, this speech leaves open the possibility that when symbolic politics are at stake, 'law' may be discarded for a 'justice' grounded in affect.

26. For example,

\begin{abstract}
America's legitimate claim of self-defense cannot be the end of the discussion. To say a military tactic is legal, or even effective, is not to say it is wise or moral in every instance. For the same human progress that gives us the technology to strike half a world away also demands the discipline to constrain that power-or risk abusing it. And that's why, over the last four years, my administration has worked vigorously to establish a framework that governs our use of force against terrorists-insisting upon clear guidelines, oversight and accountability that is now codified in Presidential Policy Guidance that I signed yesterday.
\end{abstract}

Drone Policy Speech, supra note 24.

27. The Oxford Advanced Learner's Dictionary defines "translation" as "the process of changing something that is written or spoken into another language." Translation Definition, OXFORD ADVANCED LEARNER'S DICTIONARY, http://oald8.oxfordlearnersdiction aries.com/dictionary/translation (last visited Oct. 6, 2013).

28. This understanding of translation is consistent with an "instrumental concept of language, which sees it as a mode of communication of objective information." Paula G. Rubel \& Abraham Rosman, Introduction: Translation and Anthropology, in TRANSLATING 
words, "translation" signifies the processes, expertise, and product that effects communication by bridging difference. ${ }^{29}$ However, when difference centers on conceptions of legitimacy and the legitimate foundations of authority, a less benign dynamic of translation may be at work. ${ }^{30}$ Homi Bhabha has argued that in the colonial encounter, translation has participated in, and operated as, conquest. ${ }^{31}$ Translation works as conquest when cultures are required to "revise their own systems of reference, norms and values, by departing from their habitual ... rules of transformation." 32 In other words, in contexts of domination and subordination, translation has been deployed to explore and conquer the spaces of epistemological difference. ${ }^{33}$ In this paper, I argue that the Remarks represent a moment of normative translation analogous to the colonial conquest of epistemology; a process Bhabha has characterized as "the misrule of cultural translation." 34 If the misrule of cultural translation is marked by departures and revisionsdepartures from habitual rules of transformation through revisions of systems of reference, norms, and values ${ }^{35}$-then, in the departure that is a discarded 'law' and the revision that is a reconfigured 'justice,' the Remarks are akin to the translation as misrule that marks the colonial encounter. ${ }^{36}$

In this crucial regard, translation as misrule bears little resemblance to the justice and translation that James Boyd White sees as analogous. White's true subject is "the art of recognizing another and respecting difference." 37 For White, both translation and justice are "ways of establishing right relations, both between one person and

Cultures: Perspectives on Translation and Anthropology 1, 6 (Paula G. Rubel \& Abraham Rosman eds., 2003).

29. See Naoki Sakai, Translation, 23 Theory Culture \& Soc'y 71, 75 (2006) (discussing translation as the negotiation of difference.).

30. See generally BERNARD S. COHN, COLONLALISM AND ITS FORMS OF KNOWLEDGE: THE BRITISH IN INDIA 4 (1996) (arguing that British study of Indian languages was important to the colonial project of control and command).

31. Homi K. Bhabha, The Voice of the Dom: Retrieving the Experience of the OnceColonized, TIMES LITERARY SUPPLEMENT (LONDON), Aug. 8, 1997, at 14, available at Gale, Doc. No. EX1200487824. I am grateful to Pooja Parmar for this important reference.

32. Id.

33. Id.

34. Id. (emphasis added).

35. Id.

36. See Susan Bassnett, Translating Terror, 26 THIRD WORLD Q. 393 (2005), for an explanation of the manner in which entrenched ways of thinking of Central Asia as "a cradle of savagery and anti-modernity" continue to shape the manner in which texts from an Islamist website are translated. See also TEJASWINI NIRANJANA, SITING TRANSLATION: History, POST-STRUCTURALISM, AND THE COLONIAL CONTEXT (1992), for a discussion of translation as a technology of colonial domination.

37. WHITE, supra note 2 , at 230. 
another and between a mind and the language it confronts." 38 In the warm humanism ${ }^{39}$ and compositional beauty of White's invitation to think and feel language and meaning through silence, ${ }^{40}$ and through "the music the voices make, whether beautiful and harmonious or raw and ugly," 41 there is little anticipation of the sinister instrumentality of a translation directed at the misrule of epistemological conquest. ${ }^{42}$ Despite this difference in underlying assumptions, White's acute awareness of the other-than-lexical aspects of communication points us to affect, gesture, sound, image, and feeling; tapping into what he calls "a deep sea of competence,"43

intonation, cadence, texture ... position of the body and timbre of the voice .... For language has its roots not in ideas but in social relations, and its deepest motives and meaning are social still. Think of the baby in his mother's arms: learning the language of her body, of her tones of voice and touch and gesture, and teaching her his ... words and phrases... are late and relatively minor stages in the development of his capacity to understand and respond to another person. These words float as it were on a deep sea of competence without which they would be nothing at all .... [O]ur language is at the deepest level the expression of a set of motives and gestures we share with all mammals; its radical meaning is social and relational. ${ }^{44}$

White's deep sea of competence-gestural, social, relational-in which words are but final, floating layers, is echoed by Anna Gibbs's discussion of the cross-modal and sensory translation that takes place between a mother and a nine-month old baby when a baby's delighted

38. $I d$.

39. See, e.g., id. at 232-33 ("[T] $]$ he understanding . . . we sought . . was to inhabit the world of the other, to speak Spanish, or English, with the right intonation, cadence, texture, with the right position of the body and timbre of the voice, to respond and be responded to in a whole way. That sense of human reciprocity, of shared movements, is where the deepest meaning lies.").

40. Id. at 34 .

41. Id. at 231 .

42. This is not to suggest that White is naive about the role of power relations in translation; his chapter on the influence of "Chicago School" economics shows otherwise. See id. at 46-86.

43. Id. at 233 .

44. Id. 
squeal is mirrored by a mother's responsive shimmy. ${ }^{45}$ In other words, affect is at the root of all communication; and the prelingual affective communication, and cross-modal translations between infants and parents, vividly illustrate White's conviction that affect is at the root of all translation.

At this juncture, it may be useful to clarify that affect is

\begin{abstract}
the name we give to those forces-visceral forces beneath, alongside, or generally other than conscious knowing, vital forces insisting beyond emotion-that can serve to drive us toward movement, toward thought and extension, that can likewise suspend us (as if in neutral) across a barely registering accretion of force-relations, or that can leave us overwhelmed by the world's apparent intractability. ${ }^{46}$
\end{abstract}

In other words, affect, once understood as broadly equivalent to 'emotion,' has come, in contemporary scholarship, to be understood as encompassing that which affects us, "a body's capacity to affect and to be affected." 47

How does this expansive understanding of communication and translation, with a heightened attention to affect, relate to translation as misrule in the Remarks? In the instance of the Remarks, with neither the wordless cross-modal translation of infant-parent communication, nor the conventional translation marked by difference in 'language' or 'culture,' 48 the work of translation is not immediately evident. In an effort to better grasp at the significance of the facets of communication that White disaggregates for us-gesture, affect, the

45. Anna Gibbs, After Affect: Sympathy, Synchrony, and Mimetic Communication, in THE AFFECT Theory READER 186, 195 (Melissa Gregg \& Gregory J. Seigworth eds., 2010) ("Daniel Stern describes how, when a nine-month-old girl becomes excited about a toy and is able to grasp it, she "lets out an exuberant "aah!" and looks at her mother. Her mother looks back, scrunches up her shoulders, and performs a terrific shimmy with her upper body ... . [that] is equally excited, joyful and intense' . . . Stern's account of the mother's cross-modal imitation-or translation-of the baby's squeal of delight into a dancing shimmy corresponding with its length and rhythmic contour . . makes clear ... that similarity is crucial, but so too is the difference produced in this sensory translation.").

46. Gregory J. Seigworth \& Melissa Gregg, An Inventory of Shimmers, in THE AFFECT THEORY READER, supra note 45 , at 1,1 .

47. Id. at 2 (emphasis omitted).

48. It is interesting to note that, "[o]nly recently has the term 'translation' been reduced in the scope of its meaning in the Western World to refer only to the translation from one language to another. Earlier, during the Renaissance, for example, it had many more meanings, and a much fuller semiotic range." Rubel \& Rosman, supra note 28, at 20. 
"position of the body and timbre of the voice" 49 - I rely on Walter Benjamin's notion of translation as mode:

Translation is a mode. To comprehend it as mode, one must go back to the original, for that contains the law governing the translation: its translatability. The question of whether a work is translatable ... [is]: Does its nature lend itself to translation and, there, in view of the significance of the mode, call for it? . . .

Translatability is an essential quality of certain works . . . it means ... that a specific significance inherent in the original manifest itself in its translatability. ${ }^{50}$

If the Remarks are read as a text asserting the legitimacy of the United States, then Benjamin's notion of translation as mode prompts these questions: What is the (notionally original) 'work' or 'text' that the Remarks translate? What is its nature, and what attributes of its inherent specific significance are evident in the Remarks? In framing these questions, I understand 'work' or 'text' to signify more than documentary artifact. Instead, in keeping with White's deep sea of competence, I understand the 'text' of state legitimacy to reside in the mode of an ordered set of signs-including images and sounds ${ }^{51}$ through which people understand the state to be legitimate.

My argument is straightforward: the work translated by the Remarks is a text of legitimacy that taps into the deep sea of competence that recognizes and responds to the visual, gestural, social, and relational understanding that a state conducts itself legitimately when a state presents itself in certain ways. A text of state legitimacy surely resides in the modalities of declaratory statement, public gesture, and the iconic images of state power. The pervasive understanding that state legitimacy is located in public gesture and declaratory statement comes to the forefront when contrasted with the shame, scandal, and fractured legitimacy that has (perhaps until 9/11) attached to secrecy. ${ }^{52}$ Indeed, it seems probable that the Remarks may represent the first instance of the United States making a celebratory public declaration

49. WHITE, supra note 2 , at 233.

50. BENJAMIN, supra note 17 , at 16 .

51. See Stephen P. Witte, Context, Text, Intertext: Toward a Constructivist Semiotic of Writing, 9 WRITTEN COMM. 237, 269 (1992).

52. Perhaps, in the recent history of the US, the emblematic instance of fractured legitimacy associated with the taint of secrecy is the Watergate scandal and the consequent damage to the Nixon presidency. 
with reference to a killing that arguably occupies the sphere of illegality. ${ }^{53}$

\section{B. Translation as Mode}

Translation as mode (effecting the misrule of epistemological conquest) is at work in the Remarks when iconic visual representations of state legitimacy are deployed in the performance of public gesture and when the tenor of the Remarks gravely celebrates a weighty achievement. ${ }^{54}$ For example, it is the individual who legitimately leads the United States-the President-who delivers the Remarks, making the announcement from a material space that visually signifies centuries of U.S. state authority-the White House.

53. This Senate report clarifies that up to 1975 , the U.S. had not admitted to conducting extrajudicial killings. See generally SENATE SELECT COMM. TO STUDY GOVERNMENTAL OPERATIONS WITH RESPECT TO INTELLIGENCE ACTIVITIES, AllegED Assassination Plots Involving Foreign Leaders, S. REP. No. 94-465 (1975), available at http://www.intelligence.senate.gov/pdfs94th/94465.pdf (covering allegations of United States involvement in assassination plots against foreign political leaders). In the more recent post-9/11 climate, prior to the killing of bin Laden, information on extrajudicial killings appears to have entered the public domain through leaks and comments from officials not authorized to speak. These news reports on killings in Yemen and Somalia are typical of the government's tendency to minimize publicity and links to state authority. See, e.g., Steve Bloomfield, Somalia: The World's Forgotten Catastrophe, INDEP. (Feb. 9, 2008), http://www.independent.co.uk/news/world/africa/somalia-the-worlds-forgotten-catas trophe-778225.html; Eric Schmitt, Threats and Responses: the Battlefield; U.S. Would Use Drones to Attack Iraqi Targets, N.Y. TIMES (Nov. 6, 2002), http://www.nytimes.com/2002/ 11/06/world/threats-responses-battlefield-us-would-use-drones-attack-iraqi-targets.html. After $9 / 11$, the U.S. has argued that extrajudicial killings, now somewhat euphemistically called "targeted killings," are permissible in military operations and self-defense. See Special Rapporteur on Extrajudicial, Summary or Arbitrary Executions, Study on Targeted Killings, Human Rights Council, U.N. Doc. A /HRC/14/24/Add.6, 27-28 (May 28, 2010) (by Philip Alston). In February 2013, a leaked Department of Justice White Paper revealed the Obama administration's legal justification for drone attacks on U.S. citizens. U.S. Dep't of Justice, Lawfulness of a Lethal Operation Directed Against a U.S. Citizen Who Is a Senior Operational Leader of Al-Qa'ida or an Associated Force 1, available at http://msnbcmedia.msn.com/i/msnbc/sections/news/020413_DOJ_White_Paper.pdf. In May 2013, the Obama administration acknowledge that drones had killed four U.S. citizens. See, e.g., Conor Friedersdorf, The Audacity of Eric Holder's Letter Admitting Team Obama Killed 4 Americans, ATLANTIC (May 22, 2013), http://www.theatlantic.com/politics/archive/ 2013/05/the-audacity-of-eric-holders-letter-admitting-team-obama-killed-4americans/276145/.

54. See Obama: Osama bin Laden Dead - Full Video, YouTUBE (May 1, 2011), http://www.youtube.com/watch?v=m-N3dJvhgPg, for the full video clip. 
The room from which Obama speaks is richly furnished. ${ }^{55}$ There is a pleasing symmetry in the twin lamps that flank the highly polished wood of the doors at the end of the corridor. ${ }^{56}$ An ornate chandelier casts a soft, golden light over all we see, reflecting off marble floors and walls. ${ }^{57}$ Associations with royalty are evoked by the red of Obama's tie, the red upholstery of the two gilded chairs in the frame, and the red of the carpet-all of which appear to be an identical shade of red, adding to the visual harmony of what we see.

Not only is red a color with particular affective potency, ${ }^{58}$ but the red of the carpet appears especially rich, especially royal, because it has a border of gold. And when the camera dwells on Obama's confident stride down the carpeted corridor, the plush richness of the carpet is also conveyed by the pin-drop silence that accompanies Obama's steps. In the silence that is broken only by Obama's voice, in the symmetries, the colors, and the rich beauty and golden light, there is the sense of a power that (apparently effortlessly) controls the world; this power produces an order and a sensibility in keeping with deeply entrenched understandings of power and prestige. (The control and order of the Remarks, in particular the depth of the silence that accompanies Obama's walk down the carpeted corridor to the lectern, are in stark contrast to the probable visual and aural chaos of the raid on bin Laden's compound).

Translation as mode is also at work in the manner in which Obama is presented. Although it was almost midnight at the time the Remarks were recorded, Obama looks impeccable in his suit. He shows no signs of the human need for sleep or of having performed as President and Commander-in-Chief through an especially fraught and demanding day.

55. Although the White House announcement states that the Remarks were delivered in the East Room, Macon Phillips, Osama Bin Laden Dead, THE WhiTE House BLoG (May 02, 2011, 12:16 AM), http://www.whitehouse.gov/blog/2011/05/02/osama-bin-laden-dead, the chandeliers and furniture suggest that the location of the recording was the Cross Hall, see The Art \& Décor of the White House: Public Tour by Room, http://www.white house.gov/about/inside-white-house/rooms (last visited Oct. 11, 2013) (under "State Floor," select "Cross Hall").

56. It is probable that these lamps are those described on the White House website as the bronze light standards that date from the Roosevelt renovation of 1902. See Cross Hall, THE WHITE HoUSE MUSEUM, http://www.whitehousemuseum.org/floor1/cross-hall. htm (last visited Oct. 11, 2013).

57. In The Cross Hall, the marble walls and floors were added during the Truman renovation. The two Adam-style cut-glass chandeliers were made in London in about 1775. Id.

58. See Lone Bertelsen \& Andrew Murphie, An Ethics of Everyday Infinities and Powers: Félix Guattari on Affect and the Refrain, in THE AFFECT THEORY READER, supra note 45 , at 138,138 (exploring the often unacknowledged centrality and power of affect in theory and in everyday life). 
Echoing the political theology of the two bodies of the king,59 Obama as President appears both mortal and more than mortal in his remarkable (but composed) vitality. In what must be a meticulously staged and carefully choreographed visual and aural presentation, both the President and the room appear regal; the individual who is President embodies a gravitas and certainty that surpasses human frailties, and the room that stands for the state evokes associations with wealth, power, and permanence.

To summarize, as a text of translation, the Remarks manifest the "special significance inherent in the original,"60 relating to a range of public, gestural modalities that convey state legitimacy. Translation as mode illustrates the translatability of a text that vests state legitimacy in the modalities of iconic images, public gesture, and celebratory declarations. The misrule of this translation arises from a duplicity of sorts: the mode of the 'original' text of state legitimacy is retained, but the substance of that text is altered when (conventional, institutional, and procedural) 'law' is discarded. In White's terms, the "intonation, cadence, texture ... position of the body and timbre of the voice" that constitute a text of state legitimacy are retained, but the words that are the final, floating layers of 'rule of law' restraints on state power are absent. ${ }^{61}$ Even as the delivery of the Remarks rehearses and relies on an 'original' text of legitimacy, in its content, the Remarks script departures from, and revisions of, systems of reference, norms, and values relating to the parameters of state power. It is in these departures and revisions that the translation as misrule unfolds.

\section{INESCAPABLE LAW}

\section{A. Operation as Not Law}

While an extensive and interdisciplinary critical scholarship has turned away from narrowly positivist understandings of law to instead conceptualize law as a discourse through which social and cultural meanings and relations are enacted, at the same time, as much of this same scholarship notes, dominant, popular, and received understandings of law are overwhelmingly positivist, and legal

59. See generally ERnST H. KANTOROWICZ, THE KING's Two Bodies (1957) (tracing the historical, political, and ideological complexities posed by the "King's two bodies"--the body politic and the body natural).

60. BENJAMIN, supra note 17 , at 254 .

61. WHITE, supra note 2, at 233. 
education tends to perpetuate and emphasize a positivist model of law.62 This distinction between the critical approach that informs my argument, and received notions of law, becomes important with reference to the Remarks and the events of the killing of bin Laden because Obama does not use the word 'law.' Instead, the word 'justice' features five times in the Remarks. Ironically, the nonappearance of law as an explicit term is accompanied by a cluster of familiar legal categories, including murder, terrorist, and innocence-terms through which acts, events, experiences, and our relation to the world acquire legal significance. In other words, even though an explicit 'law' is absented, the ordering effects of law are in evidence, demonstrating that law functions as a scheme of interpretation. ${ }^{63}$

It is therefore surely noteworthy that Obama uses the nonlegal term "operation" to characterize the manner in which bin Laden was killed.64 The distance and dispassion of 'operation' is associated not with law, but with the spheres of medicine and the military. In evoking the technical expertise of surgical precision and military calculations, the Remarks sidestep the range of legal categories that could have been usedexecution, extrajudicial killing, assassination, murder-categories that bring to the surface a binary that Obama may have been attempting to circumvent: legal/illegal.

Ironically, even as he avoids legal categories to characterize the U.S. action, Obama relies on legal categories to characterize bin Laden: enemy, terrorist, murderer, and violator of innocence. In selecting "operation" to characterize the U.S. action, but "enemy," "terrorist," and "murderer" to characterize bin Laden, it is as if the ordering and signifying effects of law apply to bin Laden but not to the United States. Augmenting this appropriative partitioning of law's applicability is the quality of verdict in "murderer" and "terrorist" and of uncontroversial Law of War clarity in the use of "enemy." The contrast between "operation" and enemy/murderer/terrorist is thus a subtle (and therefore especially powerful) construction of the United States as global lawmaker and law-enforcer; the United States is empowered to stand apart from the very law it scripts and relies on to condemn bin Laden. Thus it is that from the opening lines of the Remarks onwards, the long-standing myth of The Chosen Nation (discussed below) is

62. See Eve Darian-Smith, LaWS AND Societies In Global ConTEXTS 1-21 (2013), for a recent, succinct, and thorough review of the literature. See generally ELIZABETH MERTZ, THE LANGUAGE OF LAW SCHOOL: LEARNING TO "THINK LIKE A LAWYER" (2007), for a very specific consideration of the manner in which legal education perpetuates legal positivism.

63. See HANS Kelsen, PURE TheORY OF LAW 4 (1967).

64. See Remarks by the President, supra note 11 (characterizing the killing as "the operation," "this operation," "a targeted operation," and twice as "an operation"). 
invoked, with the United States implicitly claiming the ascendancy to make and enforce a law that applies to others but not to itself. ${ }^{65}$

\section{B. Enemy/Terrorist/Murderer}

Law is inescapable, functioning as a scheme of interpretation in a second vivid sense when bin Laden is rendered a legitimate target, characterized, simultaneously, as enemy/terrorist/murderer. Additionally, while Obama is careful to avoid the brute oversimplification of George W. Bush's "evil," Obama's use of "innocent"66 inevitably (because it is a lexical item that engages binary oppositions) ${ }^{67}$ positions the United States as 'innocent' and bin Laden as 'guilty.' As part of this construction, because bin Laden's guilt is presented stripped of context and cause, ${ }^{68}$ and because of the extreme nature of the 9/11 attacks and bin Laden's inflammatory language, 69 the terrorism he represents is excluded from a "view of terrorism as an expression of social conflict reflecting comprehensible grievances (albeit not necessarily justifiable)."70 With bin Laden cast as chief perpetrator of an incomprehensible and extreme violence, the main identities of the protagonists are cast: good/innocent Americans pitted against evil/guilty terrorists. ${ }^{71}$

When bin Laden is characterized as enemy/terrorist/murderer as well as violator of innocence, he is constructed as a threat in (at least) four ways. ${ }^{72}$ The confusion and contradictions that mark the U.S.

65. See Richard Falk, Encroaching on the Rule of Law: Post-9/11 Policies within the United States, in NATIONAL INSECURITY AND Human RIghts: DEMocracies Debate COUNTERTERRORISM, supra note 5, at 14, 20 (arguing that the construction of national security as the primary concern of U.S. foreign policy, particularly during the administration of George W. Bush, has been facilitated by recruiting neoconservative legal specialists who typically "have a highly skeptical attitude about whether international law should even be treated as real law").

66. See Remarks by the President, supra note 11 (describing bin Laden as "a terrorist who's responsible for the murder of thousands of innocent men, women, and children" and "committed to killing innocents in our country").

67. See Esch, supra note 20, at $387-88$, for a compendium of lexical items that necessarily imply binary oppositions, carrying the opposite cognitive association, and commonly used in the discourse of $9 / 11$.

68. See Falk, supra note 65 , at $24-25$, for a discussion of the manner in which a refusal to acknowledge, let alone address, grievances encourages the perception of "the terrorists as evil extremists."

69. See id. at 16.

70. Brysk, supra note 5 , at 4.

71. See JACKSON, supra note 6 , at 18.

72. See Brysk, supra note 5, at 4-5 (arguing that this construction has foundational implications for national security practices because the manner in which national security is approached depends, in part, on the construction of the source and nature of the threat). 
response to $9 / 11^{73}$ are in keeping with this hyperbolic and totalizing placement of bin Laden in all four categories of state responses to the violence of nonstate actors: conventional war, unconventional war, criminal violence, and, most troublingly, "as 'evildoers' beyond the scope of human community . . . forfeit[ing] even the rights of enemies or criminals."74 The manner in which bin Laden was killed, in tandem with his burial, speak to these forfeitures and prompt a multitude of (unanswered) questions that go to the heart of legitimacy in a state's exercise of coercive power.

\section{TRANSLATING LAW'S AUTHORITY}

\section{A. Law's Authority: Before and After}

If the Remarks construct a post-9/11 articulation of law's authority and represent a departure from prior grounds, the question that must be addressed is: what are these prior grounds? The intertextuality inherent to language means that long-held understandings of 'rule of law'-notions of legitimacy that predate modernity and are informed by an assumption that 'law' cannot be severed from 'justice'-are imported by, and incorporated into, contemporary understandings of law. ${ }^{75}$ And if 'rule of law' is a concept and category that straddles 'law' and 'politics' to represent legitimacy deriving from restraints on, and scrutiny of, state

73. See Falk, supra note 65, at 21-23.

74. Brysk, supra note 5 , at 4.

75. The Drone Policy Speech offers a recent example of Obama's frequent references to the Founding documents and Constitutional documents as sources of 'rule of law' and 'justice.' See Drone Policy Speech, supra note 24. For other similar references; see, for example, What is the Rule of Law?, UNITED NATIONS RULE OF LAW, http://www.unrol.org/article.aspx?article_id=3 (last visited Oct. 12, 2013) ("Aristotle said more than two thousand years ago, "The rule of law is better than that of any individual."); TAMANAHA, supra note 21, at 25 (arguing that in the standard historiography for 'rule of law' in the Anglo-American tradition, the 1215 Magna Carta is often cited as an originary moment and stating that "[n]o discussion of the Medieval origins of the rule of law would be complete without a mention of the Magna Carta"); David V. Stivison, Magna Carta in American Law, in MAGNA CARTA IN AMERICA 102, 10217 (David V. Stivison ed., 1993) (arguing that the continuing invocations of Aristotle and the Magna Carta in contemporary 'rule of law' discourse highlights the legitimizing resonance that attaches to Western antiquity, and highlights the role of narrative in constructing 'rule of law' stories). It is something of an irony that while 'rule of law' is commonly narrated as originating in classical Greek thought, this body of knowledge was lost to 'the West' for an extensive period, and "rule of law as a continuous tradition took root more than a thousand years after the heyday of Athens." TAMANAHA, supra note 21, at 7 . 
power, ${ }^{76}$ then the enduring presence of 'rule of law' in contemporary formulations of law and legitimacy speaks to the impossibility of fencing off the meanings of law, 77 whether across boundaries of time or jurisdiction. In short, 'rule of law,' understood as including-as an indispensible attribute-limits on state power, is inextricably linked to the foundations of state legitimacy. ${ }^{78}$ This then is one crucial pillar of pre-911 grounds for law's authority. ${ }^{79}$

In tandem with the intertextuality that imports long-held understandings of 'law' into contemporary parameters for state legitimacy is the centrality of narrative in constituting law's grounds of authority. Ruth Buchanan and Sundhya Pahuja draw together the strands of law, nation, narrative, and authority:

[B]oth law and nation first need to be understood in terms of their peculiarly modern natures. And one key shift that heralds modernity as a distinct period is, of course, the loss of external foundations or what is sometimes shorthanded as the 'death of God'... provok[ing] a crisis of authority such that institutions in modernity face the need to become self-founding . . . posit[ing] their sources of authority within the modern world (and often within themselves) rather than beyond the world in some transcendent source. . . . Law and nation each hold themselves out to be autonomous, legitimate and authoritative. . . . [T] hey narrate, or

76. As a category, 'rule of law' is, of course, an essentially contested concept, see generally Jeremy Waldron, Is the Rule of Law an Essentially Contested Concept (in Florida)?, 21 LAW AND PHIL. 137 (2002); and there is a vast literature explicating many meanings for 'rule of law.' However, in keeping with my declared normative stance, which sees the capacity to restrain state power as a crucial attribute of 'rule of law,' see generally RAJAH, supra note 13, an attribute deeply embedded in Western legal traditions, see generally CONSTABLE, supra note 10, and Western political traditions, see generally LOUGHLIN, SUPRA NOTE 21, and drawing on the body of literature on rule of law referenced above, see sources cited supra note 15 , my argument proceeds on the basis that restraints on, and scrutiny of, state power are a crucial aspect of 'rule of law.'

77. See, e.g., MARK DAVID AGRast et al., World Justice Project, RULE OF LAW INDEX 2012-2013 (2012-2013), available at http://worldjusticeproject.org/sites/default/files/ WJP_Index_Report_2012.pdf; Eric Holder, U.S. Att'y Gen., Speech at Northwestern University School of Law (Mar. 5, 2012), available at http://www.justice.gov/iso/opa/ag/ speeches/2012/ag-speech-1203051.html (noting his astonishing reference to rule of law); Niall Ferguson, The Rule of Law and its Enemies, THE REITH LECTURES (June 19, 2012), http://www.bbc.co.uk/programmes/b01jmx0p.

78. See MARGULIES, supra note 22.

79. The Drone Policy Speech repeatedly celebrates the role of restraints on state power and visible, public processes, pillars the Drone Policy Speech perhaps seeks to restore. See Drone Policy Speech, supra note 24. 
author [this authority] themselves. Law's narratives assert that the law is what the law says it is. And nations, too, must create themselves by narrating their own stories of origin . . . ${ }^{80}$

In short, law in the modern, secular nation-state turns away from transcendence as authority. Instead, it relies on the self-authoring, selfauthorizing narrative that ties law to that other self-authoring, selfauthorizing entity, nation. However, a paradox marks the narrative of law, nation, and authority in the specific instance of the United States. While, in keeping with the pattern Buchanan and Pahuja identify, law and nation refer to each other and find authority in each other, 81 there is a subversion of secular modernity in one crucial respect: the narrative of law, nation, and authority constructs the United States as itself transcendent.

This transcendence is evident in the political myth of "The Chosen Nation."82 Briefly, political myth is "the work on a common narrative by which the members of a social group (or society) ... make significance of their experience and deeds," 83 providing "fundamental cognitive schemata for mapping the social world ... [and thereby] reducing the

80. Ruth Buchanan \& Sundhya Pahuja, Law, Nation and (Imagined) International Communities, 8 L. TEXT CULTURE 137, 142 (2004).

81. Kramer discusses Derrida's critique of the American Declaration of Independence, "where the fact of validating that noble document turns out to have rested all along on the power that it supposedly generated." MatThEW H. KRAMER, LEgAL THEORY, POLITICAL THEORY, AND DECONSTRUCTION: AGAINST RHADAMANTHUS 120 (1991). Kramer translates Derrida's critique,

Thus, there is the "good people" that engages itself and engages itself only in signing itself, in signing its own declaration. The "we" of the declaration speaks 'in the name of the people.'

But this people does not exist. It does not exist before this declaration . ... If it gives birth to itself as a free and independent subject, as a possible signatory, that can hold only in (or with) the act of this signature.

Id. at 121 (emphasis in original); see also MARGULIES, SUPRA NOTE 22, AT 19 ("The United States is an intensely legalistic society and its reverence for the Constitution is almost limitless.").

82. In referring to the myth of The Chosen Nation, I adopt Judis' and Hughes' terminology. Jackson and Esch (following Jackson) perceive "The Chosen Nation" as an expression of "American Exceptionalism." See generally JOHN B. JUDIS, THE FOLLY OF EMPIRE: WHAT GEORGE W. BUSH COULD LEARN FROM THEODORE ROOSEVELT AND WOODROW WILSON (2004); RICHARD T. HUGHES, MYTHS AMERICA LIVES BY (2003); JACKSON, supra note 6, at 35; SEYMOUR MARTIN LIPSET, AMERICAN EXCEPTIONALISM: A DOUBLE-EDGED SWORD (1996); Esch, supra note 20.

83. BoTTICI, supra note 19 , at 133. 
complexity of social life to the relative simplicity of its narrative plot."84 Political myth meets the acute "need for a symbolic mediation of political experience" generated by the "complexity of modern societies." 85 A key distinction between narrative and political myth is that political myth is narrative that generates the affect of significance, creating a sense of proximity, shared impact, and shared relevance between individuals and nation; individuals and political events and experiences; and individuals and other individuals who constitute the imagined community of nation.

In addition to creating a sense of proximity and relevance between events and narratives on the one hand, and the individual on the other, some further key attributes of political myth are as follows: First, it layers on top of narrative in a manner that reduces complexity; Second, it is dynamic and interrelational, such that, in multiple sites, and "borne within a web of relationships . . . it is continually (re)produced, (re)interpreted, and (re)transmitted," 86 Third, political myth is richly intertextual and efficient in that fragments, symbols, and words evoke and recall "an entire body of work on a given myth ... giv[ing] meaning . . . beyond what is actually said," 87 Fourth, political myth tends to frame issues in such a manner that certain responses are precluded while others are encouraged, typically in a manner that legitimizes policy. ${ }^{88}$ Finally, and most potently, political myth tends to be ubiquitous, invisible, and taken for granted, in part because these myths have long been in existence and speak in imperceptible ways to a group perception of political conditions and experiences. ${ }^{89}$

In locating political myth as a field, Chiara Bottici argues that dominant thinking in contemporary political philosophy, as epitomized by John Rawls' Theory of Justice and Jurgen Habermas' Between Facts and Norms, proceeds on the assumption that when it comes to political actors and the sphere of politics, "one can count on the rationality of the actors involved" either as "rationality with regard to ends and values, or as communicative rationality." 90 Such an assumption risks failing to account for a social reality in which "quite often, people seem to act on the basis of arational elements, ... powerful symbols and images of the world, which are not taken into account by a purely rational image of

84. Id. at 179.

85. Id. at 132 .

86. Esch, supra note 20 , at 362 . See also MARGULIES, supra note 22 , at $5-41$, for a recent account of the deeply relational and socially pervasive nature of political myth in the United States.

87. Esch, supra note 20, at 362-63.

88. See id. at 363.

89. See id. at 364 .

90. BOTTICI, supra note 19 , at 1 \& n.1. 
politics."91 Given the pervasive, powerful, and either invisible or barely visible workings of political myth, it is instructive to unpack the manner in which the political myth of The Chosen Nation informs the Remarks.

The Chosen Nation is characterized by the sense that the United States is "qualitatively different from other societies."92 A conviction in an exceptional status and quality is not, of course, unique to the United States as a nation. However, the United States is unique in history because

America, unlike Britain, Nazi Germany, or the Soviet Union, has yet to suffer a crushing setback to its hopes. Over the last three centuries, America has steadily risen in prosperity and power. As a result, successive generations have passed on the belief that the United States has a special role in the world. ${ }^{93}$

Augmenting this convergence of history and political myth is the realpolitik of the United States' strategic global presence. When the Remarks open with Obama reporting "to the American people and to the world that the United States has conducted an operation that killed Osama bin Laden," there is an awareness that U.S. action is alwaysalready global in impact. ${ }^{94}$ In his assessment of the United States' post9/11 encroachments on the rule of law, Richard Falk highlights that the confused and often unconvincing nature of U.S. responses to $9 / 11$ is crucially linked to the factor of the global:

[T] he specificities of the American situation . . . make it a case apart . . . . [The U.S. is] the one and only global state, with strategic interests and military deployments spread around the entirety of the globe. In this respect considerations other than counterterrorism became so influential in shaping the American response to $9 / 11$ as to overwhelm the manifest security concerns raised by even terrorist threats of unprecedented magnitude. ${ }^{95}$

91. Id. at 1 .

92. Esch, supra note 20, at 366 .

93. John B. Judis, The Author of Liberty: Religion and U.S. Foreign Policy, DISSENT, Fall 2005, at 54, 56 .

94. Remarks by the President, supra note 11 (emphasis added).This particular killing most certainly played out in a global territorial theatre, with references to Afghanistan, Pakistan, and the globe running throughout the Remarks. See id.

95. Falk, supra note 65 , at 14. 
Political myth, history, and geo-politics layer upon the deeply religious roots of the myth of The Chosen Nation ${ }^{96}$-roots that remain evident in the three main ideas of The Chosen Nation, "the idea of the United States as God's 'chosen nation' . . . is the idea that the United States has a 'mission' or a 'calling' to transform the world . . . [and] in carrying out this mission, the United States is representing the forces of good over evil."97

This mission-driven zeal of The Chosen Nation reverberates in the United States-as-transcendent declarations with which the Remarks end:

[T]oday's achievement [the killing of bin Laden] is a testament to the greatness of our country and the determination of the American people.... [W] are once again reminded that America can do whatever we set our mind to. That is the story of our history, whether it's the pursuit of prosperity for our people, or the struggle for equality for all our citizens; our commitment to stand up for our values abroad, and our sacrifices to make the world a safer place. ... [W]e can do these things not just because of wealth or power, but because of who we are: one nation, under God, indivisible, with liberty and justice for all. ${ }^{98}$

In re-articulating The Chosen Nation by translating its long-held ideas into a contemporary account, this excerpt illustrates how the secular modernity of law/nation/authority is subverted: the killing of bin Laden becomes an expression of U.S. national virtues in tandem with an (implicit) erasure of 'law' when an extrajudicial, extraterritorial act of state violence becomes emblematic of "the greatness of our country" in

96. See supra note 82.

97. John B. Judis, CARnegie Endowment for InT'L PEACE, The Chosen Nation: The INFLUENCE OF RELIGION ON U.S. FOREIGN POLICY 1-2 (2005), available at http://carnegie endowment.org/files/PB37.judis.FINAL.pdf.

98. Remarks by the President, supra note 11. This last phrase, the substantive closing of the Remarks, repeats the closing line of the Pledge of Allegiance; appropriating longheld associations with patriotism for the act of killing bin Laden. In tracing the contestations between a secularism drawn from Enlightenment thought, and religiousity as a founding value of U.S. society, Margulies highlights the manner in which the last six words of the Pledge of Allegiance, "with liberty and justice for all," written in 1892, reflect Enlightenment values. In contrast, "under God" was a very recent addition; added in the Cold War context of 1954 in an effort to distinguish the U.S. from the "godless communism." See MARGULIES, supra note 22, at 24-25 (analyzing the relationship between the Pledge of Allegiance and Enlightenment values). 
both the national arena ("prosperity for our people . . equality for all our citizens"), and the international arena ("our commitment to stand up for our values abroad, and our sacrifices to make the world a safer place"). By casting extraterritorial aggression as selfless, sacrificial, and ethically motivated, the assertion is that such acts of violence are (affectively, transcendentally) legitimate. The foundation of that legitimacy is not national or international doctrinal law but the selfscripted ascendency of the United States as The Chosen Nation.

\section{B. The Chosen Nation and Justice}

If, in the Remarks, The Chosen Nation works to subvert law's secular modernity, then this next section illustrates the manner in which an amplification of affect translates 'justice' into a substitute for 'law.' Instead of secular modernity's standard narrative of law/nation/authority, 99 the Remarks narrate The Chosen Nation/affective justice/United States as transcendent authority. This subversion of secular modernity's law is especially evident in the way the Remarks make (affective) sense of 9/11, when 'nation' becomes the site of a significance that is simultaneously public yet intimate:

It was nearly 10 years ago that a bright September day was darkened by the worst attack on the American people in our history. The images of $9 / 11$ are seared into our national memory-hijacked planes cutting through a cloudless September sky; the Twin Towers collapsing to the ground; black smoke billowing up from the Pentagon; the wreckage of Flight 93 in Shanksville, Pennsylvania, where the actions of heroic citizens saved even more heartbreak and destruction.

The role of significance in political myth (rendering narrative relevant, proximate, and felt), is overt when the 'nation' becomes one traumatized body sharing one indelible national memory. This political myth is constructed in language that heightens the senses of touch, smell, sight, and sound and the affect of trauma, loss, and grief, with the repeated harsh consonant ' $\mathrm{k}$ ' (hijacked, cloudless, cutting) underpinning the violence of that trauma.

When the narrative line moves from the public space of the iconic images of $9 / 11$ to the domestic spaces of nation, that which is private

99. See Buchanan and Pahuja, supra note 80. 
and unseen is again rendered into a shared affective experience, this time even more intimately portrayed:

And yet we know that the worst images are those that were unseen .... The empty seat at the dinner table. Children who were forced to grow up without their mother or their father. Parents who would never know the feeling of their child's embrace. Nearly 3,000 citizens taken from us, leaving a gaping hole in our hearts.

The lexical chain "forced . . . never . . . taken," culminating in the permanent "gaping hole in our heart," underlines the triple violence of death, unforeseeable death, and unforeseeable death on a large scale. The familial, very intimate, and domestic experiences of loss become national (and nation making) when made to manifest in a civic embodiment with a single punctured heart. In this way, the affect of love, grief, and loss spans and yokes the sphere of both private and public, such that the story of nation coheres around this felt, collectively embodied, loss. 9/11 is (affectively) renewed and revitalized to become the foundation of a 'justice' stripped of 'law.'

\section{Affect, Nation, and Civic Community}

The narrative arc of the Remarks shifts the nation from shock, grief, and trauma to the celebration of an idealized civic community presenting a shared affect of love and grief as the catalyst for this shift. The shared love and grief rescues the nation from collapse and galvanizes it into a healing unity. Transcending the barriers of difference, 'family' becomes 'community' becomes 'nation':

On September 11, 2001, in our time of grief, the American people came together. We offered our neighbors a hand, and we offered the wounded our blood. We reaffirmed our ties to each other and our love of community and country. On that day, no matter where we came from, what God we prayed to, or what race or ethnicity we were, we were united as one American family.

The centrality of affect in the Remarks continues with a personification of the United States; vividly embodied as a single, grieving, giving, sensing, body: extending a hand, sharing blood, affirming ties, and feeling love. For this personified United States, 
images are seared into a single memory. Later in the Remarks, vigor is reclaimed through a single mind, "America can do whatever we set our mind to." Not only does 'family' become 'community' become 'nation,' the circle of significance is closed with 'nation' becoming a single, sensing, body; unified in its affective experience.

In narrating the unity of "one American family," Obama rehearses

a myth of American nationality that remains vital in our political and cultural life: the idealized self-image of a multiethnic, multiracial democracy, hospitable to difference but united by a common sense of national belonging. 100

Indeed, as the first nonwhite President of the United States, Obama embodies the promise and potential of this myth in an especially poignant way. But this relatively recent mythology of the United States as multiethnic and multiracial (Richard Slotkin dates it from the early $1940 \mathrm{~s}^{101}$ ) is in tension with an older, deeply entrenched, deeply raced political myth of U.S. identity, the Myth of the Frontier.

[D]eveloped between 1780 and 1850, the myth depicts America as a racial entity: a white Anglo-Saxon Protestant nation, which defines itself by destroying or subjugating a "non-white" enemy-Native Americans and Mexicans. Although African Americans were part of American society during this period, the myth treats them as internal aliens, "others," and potential enemies of "the white republic." In doing so, the myth reflects the reality of an American society which had adopted a "whites only" limitation of American citizenship. . . . The central characters of the Frontier Myth represent parties to a racial conflict, and the narrative action of the myth tells us that such a conflict is inevitably violent. Social relations among whites are always seen to be based on mutual consent, and therefore democratic; but whites can deal with Indians only through force, by exterminating or subjugating them-that is, ruling them by force, without their consent. I call this concept the

100. Richard Slotkin, Unit Pride: Ethnic Platoons and the Myths of American Nationality, 13 AM. LITERARY HIST. 469, 469 (2001).

101. See id. 
"savage war" myth, and it is an aspect of the Frontier Myth . . . .102

Through an analysis of myth, race, and nation in the genre of combat films, Slotkin argues that, in life as on screen, the enemy as dehumanized, savage, and racial Other becomes the narrative trope that enables the United States, as nation, to "put difference aside and work together against an enemy who is both evil and overwhelmingly powerful." 103

The unresolved tension between these competing myths of U.S. identity-multiethnic civic community ${ }^{104}$ versus whites-only Frontier Myth-is marked by a near-absence in the Remarks. ${ }^{105}$ In his idealized picture of "love of community and country," Obama chooses to minimally acknowledge (in a peripheral mention toward the end of the Remarks) ${ }^{106}$ the post-9/11 violence directed, within the United States, at a raced category: "persons who appear to be 'Middle Eastern, Arab, or Muslim'."107

Leti Volpp points out that U.S. state policy and practice has played a role in the more than one thousand incidents of violence, which occurred within just a year of $9 / 11$, directed at those who belong to this post-9/11 identity category. 108 Though this violence was perpetrated by "the general public,"109 Volpp sees this aggression as expressions of the race-related governmentality formulated and enacted by the U.S. state in response to $9 / 11$,

In simultaneously advocating policies of color blindness for citizenry while engaging in racial profiling for noncitizens, and publicly embracing all religions, while particularly privileging Christianity, the administration has, in the name of democratic inclusion, disingenuously excluded. That an epidemic of hate violence has occurred

102. Id. at 473 .

103. Id. at 479 .

104. Smith traces the consolidation of ideologies marginalizing the already marginalized, such as women, non-whites, and the poor, to the Progressive Era (18981912). Rogers SMITH, CIVIL IdeALS: CONFLICTING VISIONS OF CiTIZENSHIP IN U.S. HISTORY 410-420 (1997).

105. See id. passim.

106. Toward the closing of the Remarks, Obama acknowledges that, "the sense of unity that prevailed on $9 / 11$. . . has, at times, frayed." Remarks by the President, supra note 11 .

107. Leti Volpp, The Citizen and the Terrorist, in SEPTEMBER 11 IN HISTORY 147, 147 (Mary L. Dudziak ed., 2003).

108. Id.

109. Id. at 149. 
within the context of "private" relations thus does not mean that such violence is without "public" origins or consequences. ${ }^{110}$

In highlighting the manner in which this post-9/11 identity category has resulted in a fracturing of civic community, "members of this group have been identified as terrorists, and disidentified as citizens." 111 Volpp's essay may be read as a counter-narrative to the idealized multiethnic harmony constructed by the Remarks. This vulnerability to being disidentified as 'citizen' has, as Volpp points out, disturbing precedent in the United States' internment of Japanese citizens during World War II, and significantly, was not an outcome of the Oklahoma City bombing:

Timothy McVeigh failed to produce a discourse about
good whites and bad whites, because the public
conceptualized McVeigh as an individual deviant ....
His actions were not considered representative of an
entire racial group. This is ... how racial subordination
functions: to understand nonwhites as directed by
group-based determinism but to see whites as
individuals. 112

The contrast is striking. By refusing to conceive of bin Laden as a deviant individual and, instead, fostering systemic racial profiling, the deep undercurrents of the Myth of the Frontier (necessitating savage war against a fully dehumanized enemy), might be seen to be at work. ${ }^{113}$ The enduring resonance of this aspect of U.S. political myth is one way of explaining both the propensity to racialized exclusions from 'nation' that Volpp traces and the widespread acceptance within the United States for the manner in which bin Laden was killed and buried. Most crucially, the continuing significance of the Myth of the Frontier explains how violence directed at the dehumanized, savage, racially Other enemy ${ }^{114}$ serves the transcendence of the United States in two senses. First, this violence is in continuity with long-entrenched understandings of a 'justice' that has no need for the institutions, processes, and actors of secular modernity's law; and second, this violence is 'just' also because it consolidates the 'nation,' healing

110. Id. at 150-51.

111. Id. at 147.

112. Id. at 151 .

113. See Slotkin, supra note 100.

114. See id. at 479. 
internal fractures by casting a shared affective significance of U.S. political experience as the transcendent value.

\section{Civic Versus Global Communities}

If the one and only global nation needs an external enemy to heal the internal fractures of 'nation,' then the political myth of The Chosen Nation accounts for the manner in which 9/11 could not be permitted to be framed in transnational terms. Instead, The Chosen Nation took expression in its (perhaps unexpected) variation of exceptional victim..$^{115}$

In emphasizing American ownership and experience of the tragedy and trauma of 9/11 ("Nearly 3,000 citizens taken from us"), the Remarks are consistent with prior U.S. official rhetoric in choosing not to frame the events in a manner that might build a transnational and humanist solidarity:

[O]fficial rhetoric overwhelmingly depicted Americans as a special, united people suffering a uniquely obscene tragedy. Alternatively, the rhetoric could have framed the events as an attack on humanity or expressed solidarity with victims of political violence in other countries. However, through continual emphasis of American ownership of the tragedy, the official rhetoric succeeded in bestowing upon America the politically valuable status of primary victim. As Bowman has pointed out, creating or sustaining a sense of national victimhood and grievance promotes a discourse of violence that rallies support for war. . . . [I]t serve[s a] political purpose. ${ }^{116}$

Thus, while it may seem hopelessly contradictory for the political myths at work to simultaneously construct The Chosen Nation in terms of superiority as well as in terms of victimhood, the underlying rationale is coherent: American suffering is qualitatively different from the suffering of non-Americans. Implicitly, the suffering of America as nation, and Americans as citizens, becomes the authority for departing from law, turning instead to a justice founded in the affect of grief.

In her poignant response to 9/11, novelist Barbara Kingsolver recounts moments of natural calamity and political violence that have killed thousands in horrifically condensed moments and, tellingly,

115. See JACKSON, supra note 6, at 35 (characterizing this as "Exceptional Grievance").

116. Esch, supra note 20, at 373 (internal citations omitted). 
reminds readers that, three and a half years after the Japanese bombing of Pearl Harbor, "American planes bombed a plaza in Japan where men and women were going to work, where schoolchildren were playing, and more humans died at once than anyone thought possible. Seventy thousand in a minute. Imagine." 117

I draw attention to Kingsolver's piece, not because I want to quantify violence in terms of body counts, but because it conveys, so powerfully, the manner in which the discourse of the exceptional victim expresses, in a different thematic form, the myth of The Chosen Nation. In treating America, and American suffering as qualitatively different from other peoples in other places, The Chosen Nation is expressed anew in the form of an apartness: apart both from the rest of the world and from (relatively recent) historic events. Isolationism and the exaltation of the United States (even if it is the exaltation of pain) go hand-in-hand and return us to Bottici's emphasis on the role of significance in the processes of reproducing and reformulating political myths. New events and circumstances may generate variations on the theme of The Chosen Nation, ${ }^{118}$ but the logic of indifference to that which occurs in not-America, to not-Americans, remains. ${ }^{119}$

\section{HEaling the (ChOSEN) Nation: NaRRATiNG JUStice}

With the insistence that the American people are united, loving, and neighborly, the killing of bin Laden becomes an opportunity to renarrate the nation, minimizing the fractures of racialized public and private violence such that nation, as loving community, becomes a healing trope. After all, "[c]onstructing a memory involves forgetting. Creating the narrative structure of a memory requires us to choose what to place in the story, and what to leave out." 120 Obama's decision to almost completely leave out the post-9/11 failures of 'citizen' is consistent with "the attempt by nationalist discourses persistently to

117. Barbara Kingsolver, A Pure, High Note of Anguish, L.A. TrMES, Sept. 23, 2001, at M8.

118. Perhaps the events of the Boston bombings, as they have come to be known, offer a recent example, particularly in the extraordinary inflation of the language of "weapons of mass destruction" used in the charge. In addition to establishing a lexical and rhetorical link to Saddam Hussein, the use of "weapons of mass destruction" raises the following question: if home-made pressure cooker bombs are "weapons of mass destruction," what then does nuclear weaponry become?

119. One very troubling and on-going expression of this aspect of The Chosen Nation is evident in the official and popular justifications relating to the use of drones in Afghanistan, Pakistan, and Yemen.

120. Mary L. Dudziak, Afterword: Remembering September 11, in SEPTEMBER 11 IN HISTORY, supra note 111 , at $212,213$. 
produce the idea of the nation as a continuous narrative of national progress, the narcissism of self-generation, the primeval present of the Volk."121

This narration of nation is also significant in terms of narrating 'justice' into being when Obama moves from recounting the healing nation to a cause-and-effect narrative of a justified war, ("The American people did not choose this fight. It came to our shores, and started with the senseless slaughter of our citizens"); a war embarked upon to protect those who matter, "our citizens, our friends, and our allies."

In directing the narrative from the motif of healing and civic community to the attainment of justice, the Remarks present a particular subset of social actors as key: military, intelligence, and counterterrorism personnel. If the military has long been understood to be "the instrument of American patriotism," 122 the manner in which the categories 'counterterrorism professionals' and 'intelligence community' are situated alongside the military is surely significant. The term 'spies' is not used, but it lurks beneath the surface of 'counterterrorism professionals' and 'intelligence community.' In celebrating those who work in counterterrorism and intelligence, the Remarks firmly relocate 'spies' from the shadowy realm of deception and treachery to the valorized realm of the heroic and virtuous. There is no acknowledgement of the shame and scandal attaching to the horrific abuses of (military, intelligence, and counterterrorism) power invoked by names like Abu Ghraib and Guantanamo. ${ }^{123}$ In this movement and redefinition with regard to the cast of justice actors, we see yet another mode of translation at work; a mode of translation which moves actors and redefines their roles, as explicated by Callon. ${ }^{124}$

121. Homi K. Bhabha, Introduction: Narrating the Nation, in NATION AND NARRATION 1 , 1 (Homi K. Bhabha ed.,1990) (emphasis omitted).

122. Slotkin, supra note 100 , at 477.

123. In contrast, it is noteworthy that, in the Drone Policy Speech, Obama seeks to implicitly distinguish the conduct of the Bush Presidency, which "us[ed] torture to interrogate our enemies, and detain[ed] individuals in a way that ran counter to the rule of law," from the strategies of his administration, which has "unequivocally banned torture, affirmed our commitment to civilian courts, worked to align our policies with the rule of law, and expanded our consultations with Congress." Drone Policy Speech, supra note 24. Toward the end of the Drone Policy Speech, he asserts "we commit to a process of closing GTMO . . consistent with our commitment to the rule of law." Id.

124. Michel Callon, Some Elements of a Sociology of Translation: Domestication of the Scallops and the Fishermen of St Brieuc Bay, in POWER, ACTION AND BELIEF: A NEW SocIOLOGY OF KNOWLEDGE? 196-223 (John Law ed. 1986). I am grateful to Colin Ford for this invaluable reference and for access to Ford's Dungeons and Dragons: Controversy, Translation, and Occult Gaming (copy on file with author), which applies Callon's argument in an illuminating and engaging manner. 
If 'law' and 'rule of law' are terms that represent state power that is visible, scrutinized, and accountable, then a shift in the parameters of legitimacy is effected when those who work in the hidden worlds of counterterrorism and intelligence are publicly celebrated, even as their exclusion from public scrutiny is cast as an expression of individual and national virtue. The Remarks repeatedly celebrate military, counterterrorism, and intelligence personnel for work that is tireless, heroic, painstaking, courageous, skillful, professional, patriotic, and self-sacrificing. The sacralizing language with which this new cast of justice actors (and their work) is constructed provides an authority for 'justice' that returns the foundations of that authority to 'nation.' However, very specifically, the 'justice' constructed by the Remarks does not situate justice's authority in the secular, modern nation-state. Instead, the Remarks bring 'justice' into being by relying on The Chosen Nation, reinscribing, as we have seen, the United States as itself transcendent:

Tonight, we give thanks to the countless intelligence and counterterrorism professionals who've worked tirelessly to achieve this outcome.... We give thanks for the men who carried out this operation, for they exemplify the professionalism, patriotism, and unparalleled courage of those who serve our country. ... [W] e are: one nation, under God, indivisible, with liberty and justice for all. ... May God bless you. And may God bless the United States of America.

Importantly, this sacralizing of the United States, and of the personnel who serve America-the military, intelligence and counterterrorism personnel-again deploys affect (determination, sacrifice, courage, patriotism, service) within a rhetorical framework that recalls the cadence of a (Christian) sermon. This sacralizing language elevates the new justice actors to a space beyond scrutiny or knowability. They are invisible because of the (virtuous and selfsacrificing) nature of their work, and the justification for this invisibility is experienced as a feeling and in the manifestation of justice: "The American people do not see their work, nor know their names. But tonight, they feel the satisfaction of their work and the result of their pursuit of justice." 125

In short, 'justice' is authorized by shared feelings; an affective conviction in the United States as transcendent. In the process, what is

125. Remarks by the President, supra note 11. 
toppled is a secular law. If law, in particular 'rule of law,' scrutinizes power, values transparency, and seeks clarity as to normative content, then 'justice' in the post-9/11 world of the Remarks resides in the production (and disposal) of dead bodies and in feelings that are bordered as American in ideological, territorial, and profoundly mythic terms.

\section{CONCLUSION: RECOVERING THE 'LAW' IN 'LEGITIMACY'}

If language and conduct embody the rules and values that are law, then a major announcement like the Remarks cannot be dismissed as the empty rhetoric of a politician, nor can the manner in which bin Laden was killed be minimized as an exception. Law is embodied and enacted by the text of the Remarks and the text of this killing. It is a law that has uncoupled 'law' and 'justice,' celebrating secretive state actors and elevating an extra-judicial killing into an emblem of national virtue and international ascendancy. Together, the killing of bin Laden and the text of the Remarks have reconfigured the very grounds of state legitimacy.

And yet the violations of 'law' and legitimacy of this reconfiguration are not immediately apparent, and this is where translation has played a major role. A strategic disaggregation-a bifurcated translation-has enabled the performance of legitimacy through the affect of gesture, image, sound, and significance, even as norms, actors, roles, and systems have been reconfigured, moved, and re-defined. The discarding of established legal and judicial processes is barely noticeable when we are wrapped in a womb-like affect of significance designed to climax in a felt and retributive 'justice.' This felt justice becomes the grounds of a legitimacy that celebrates U.S. political myth as an authorizing and legitimizing transcendence that has no need for transparency, the scrutiny of power, or visible public processes. The abandonment of the 'law' of secular modernity pales into insignificance when paired with the ample and seductive affect of political myth.

This translation is all the more sinister because it is coherent with a range of ways in which U.S. state power continues to be exercised in a post-9/11 world in which torture, detention without trial, and extrajudicial killings have come to be normalized as long as these occur in distant places upon the bodies of distant Others. If a crucial attribute of 'rule of law' is contained in the fragile crucible of law's capacity to strive for an apartness from power and to use this (notionally) separate standing to scrutinize and limit power through institutions, processes, and actors who are visible and public, then recognizing the operations of translation may help alert us to ways in which conceptions of state 
legitimacy are uncoupling 'law' and 'justice,' even as perceptions of that legitimacy rely on sinister translations. 


\section{APPENDIX A: REMARKS BY THE PRESIDENT ON OSAMA BIN LADEN}

Office of the Press Secretary

For Immediate Release

May 02, 2011

Remarks by the President on Osama Bin Laden

East Room

11:35 P.M. EDT

THE PRESIDENT: Good evening. Tonight, I can report to the American people and to the world that the United States has conducted an operation that killed Osama bin Laden, the leader of al Qaeda, and a terrorist who's responsible for the murder of thousands of innocent men, women, and children.

It was nearly 10 years ago that a bright September day was darkened by the worst attack on the American people in our history. The images of $9 / 11$ are seared into our national memory-hijacked planes cutting through a cloudless September sky; the Twin Towers collapsing to the ground; black smoke billowing up from the Pentagon; the wreckage of Flight 93 in Shanksville, Pennsylvania, where the actions of heroic citizens saved even more heartbreak and destruction.

And yet we know that the worst images are those that were unseen to the world. The empty seat at the dinner table. Children who were forced to grow up without their mother or their father. Parents who would never know the feeling of their child's embrace. Nearly 3,000 citizens taken from us, leaving a gaping hole in our hearts.

On September 11, 2001, in our time of grief, the American people came together. We offered our neighbors a hand, and we offered the wounded our blood. We reaffirmed our ties to each other, and our love of community and country. On that day, no matter where we came from, what God we prayed to, or what race or ethnicity we were, we were united as one American family.

We were also united in our resolve to protect our nation and to bring those who committed this vicious attack to justice. We quickly learned that the 9/11 attacks were carried out by al Qaeda-an organization headed by Osama bin Laden, which had openly declared war on the United States and was committed to killing innocents in our country and around the globe. And so we went to war against al Qaeda to protect our citizens, our friends, and our allies.

Over the last 10 years, thanks to the tireless and heroic work of our military and our counterterrorism professionals, we've made great strides in that effort. We've disrupted terrorist attacks and 
strengthened our homeland defense. In Afghanistan, we removed the Taliban government, which had given bin Laden and al Qaeda safe haven and support. And around the globe, we worked with our friends and allies to capture or kill scores of al Qaeda terrorists, including several who were a part of the $9 / 11$ plot.

Yet Osama bin Laden avoided capture and escaped across the Afghan border into Pakistan. Meanwhile, al Qaeda continued to operate from along that border and operate through its affiliates across the world.

And so shortly after taking office, I directed Leon Panetta, the director of the CIA, to make the killing or capture of bin Laden the top priority of our war against al Qaeda, even as we continued our broader efforts to disrupt, dismantle, and defeat his network.

Then, last August, after years of painstaking work by our intelligence community, I was briefed on a possible lead to bin Laden. It was far from certain, and it took many months to run this thread to ground. I met repeatedly with my national security team as we developed more information about the possibility that we had located bin Laden hiding within a compound deep inside of Pakistan. And finally, last week, I determined that we had enough intelligence to take action, and authorized an operation to get Osama bin Laden and bring him to justice.

Today, at my direction, the United States launched a targeted operation against that compound in Abbottabad, Pakistan. A small team of Americans carried out the operation with extraordinary courage and capability. No Americans were harmed. They took care to avoid civilian casualties. After a firefight, they killed Osama bin Laden and took custody of his body.

For over two decades, bin Laden has been al Qaeda's leader and symbol, and has continued to plot attacks against our country and our friends and allies. The death of bin Laden marks the most significant achievement to date in our nation's effort to defeat al Qaeda.

Yet his death does not mark the end of our effort. There's no doubt that al Qaeda will continue to pursue attacks against us. We must-and we will-remain vigilant at home and abroad.

As we do, we must also reaffirm that the United States is not-and never will be-at war with Islam. I've made clear, just as President Bush did shortly after $9 / 11$, that our war is not against Islam. Bin Laden was not a Muslim leader; he was a mass murderer of Muslims. Indeed, al Qaeda has slaughtered scores of Muslims in many countries, including our own. So his demise should be welcomed by all who believe in peace and human dignity. 
Over the years, I've repeatedly made clear that we would take action within Pakistan if we knew where bin Laden was. That is what we've done. But it's important to note that our counterterrorism cooperation with Pakistan helped lead us to bin Laden and the compound where he was hiding. Indeed, bin Laden had declared war against Pakistan as well, and ordered attacks against the Pakistani people.

Tonight, I called President Zardari, and my team has also spoken with their Pakistani counterparts. They agree that this is a good and historic day for both of our nations. And going forward, it is essential that Pakistan continue to join us in the fight against al Qaeda and its affiliates.

The American people did not choose this fight. It came to our shores, and started with the senseless slaughter of our citizens. After nearly 10 years of service, struggle, and sacrifice, we know well the costs of war. These efforts weigh on me every time I, as Commander-in-Chief, have to sign a letter to a family that has lost a loved one, or look into the eyes of a service member who's been gravely wounded.

So Americans understand the costs of war. Yet as a country, we will never tolerate our security being threatened, nor stand idly by when our people have been killed. We will be relentless in defense of our citizens and our friends and allies. We will be true to the values that make us who we are. And on nights like this one, we can say to those families who have lost loved ones to al Qaeda's terror: Justice has been done.

Tonight, we give thanks to the countless intelligence and counterterrorism professionals who've worked tirelessly to achieve this outcome. The American people do not see their work, nor know their names. But tonight, they feel the satisfaction of their work and the result of their pursuit of justice.

We give thanks for the men who carried out this operation, for they exemplify the professionalism, patriotism, and unparalleled courage of those who serve our country. And they are part of a generation that has borne the heaviest share of the burden since that September day.

Finally, let me say to the families who lost loved ones on 9/11 that we have never forgotten your loss, nor wavered in our commitment to see that we do whatever it takes to prevent another attack on our shores.

And tonight, let us think back to the sense of unity that prevailed on 9/11. I know that it has, at times, frayed. Yet today's achievement is a testament to the greatness of our country and the determination of the American people.

The cause of securing our country is not complete. But tonight, we are once again reminded that America can do whatever we set our mind 
to. That is the story of our history, whether it's the pursuit of prosperity for our people, or the struggle for equality for all our citizens; our commitment to stand up for our values abroad, and our sacrifices to make the world a safer place.

Let us remember that we can do these things not just because of wealth or power, but because of who we are: one nation, under God, indivisible, with liberty and justice for all.

Thank you. May God bless you. And may God bless the United States of America.

END 11:44 P.M. EDT 
